\title{
Electronic outlining as a writing strategy: Effects on students' writing products, mental effort and writing process
}

Citation for published version (APA):

De Smet, M., Brand-Gruwel, S., Leijten, M., \& Kirschner, P. A. (2014). Electronic outlining as a writing strategy: Effects on students' writing products, mental effort and writing process. Computers \& Education, 78, 352-366. https://doi.org/10.1016/j.compedu.2014.06.010

DOI:

10.1016/j.compedu.2014.06.010

Document status and date:

Published: 01/09/2014

Document Version:

Other version

Please check the document version of this publication:

- A submitted manuscript is the version of the article upon submission and before peer-review. There can be important differences between the submitted version and the official published version of record. People interested in the research are advised to contact the author for the final version of the publication, or visit the DOI to the publisher's website.

- The final author version and the galley proof are versions of the publication after peer review.

- The final published version features the final layout of the paper including the volume, issue and page numbers.

Link to publication

\section{General rights}

Copyright and moral rights for the publications made accessible in the public portal are retained by the authors and/or other copyright owners and it is a condition of accessing publications that users recognise and abide by the legal requirements associated with these rights.

- Users may download and print one copy of any publication from the public portal for the purpose of private study or research.

- You may not further distribute the material or use it for any profit-making activity or commercial gain

- You may freely distribute the URL identifying the publication in the public portal.

If the publication is distributed under the terms of Article $25 \mathrm{fa}$ of the Dutch Copyright Act, indicated by the "Taverne" license above, please follow below link for the End User Agreement:

https://www.ou.nl/taverne-agreement

Take down policy

If you believe that this document breaches copyright please contact us at:

pure-support@ou.nl

providing details and we will investigate your claim.

Downloaded from https://research.ou.nl/ on date: 26 Apr. 2023 


\title{
Electronic outlining as a writing strategy: Effects on students' writing products, mental effort and writing process.
}

\author{
de Smet, Milou J.R., ${ }^{1,2}$ milou.desmet@uantwerpen.be,milou.desmet@ou.nl \\ Brand-Gruwel, Saskia1 Saskia.Brand-Gruwel@ou.nl \\ Leijten, Mariëlle ${ }^{2,3}$ Marielle.Leijten@uantwerpen.be \\ Kirschner, Paul A. ${ }^{1}$ Paul.Kirschner@ou.nI \\ ${ }^{1}$ Open University in the Netherlands, Welten Institute, Research Centre for Learning, Teaching and \\ Technology, P.O. Box 2960, 6401, DL Heerlen, The Netherlands \\ ${ }^{2}$ University of Antwerp, Faculty of Applied Economics, Department of Management, Prinsstraat 13, 2000, \\ Antwerp, Belgium \\ ${ }^{3}$ Research Foundation - Flanders (FWO), Belgium
}

\section{KEYWORDS:}

Electronic outlining

Mental effort

Secondary education

Writing process

Writing strategies

\section{Abstract}

This study addresses to what extent and how electronic outlining enhances students' writing performance. To this end, the focus of this study is not only on students' final writing products but also on the organisation of the writing process (i.e., planning, translating, and reviewing) and perceived mental effort during writing. In addition, effects of repeated electronic outlining were examined. A combined within and between subjects design was implemented in which 93 10th-grade students wrote two argumentative texts with or without using electronic outlining. Analyses showed that using electronic outlining for planning and writing significantly improved the presentation of the argumentative structure. However, effects were less clear for correctly and completely establishing a text structure and no effects were found on the elaboration of students' argumentation. Process data showed that electronic outlining increased total process time, but no effect was found on students' overall planning and revision activities. Finally, self-reports showed no effect of electronic outlining on students' perceived mental effort. Nevertheless, repeated use of the same writing strategy enhanced writing fluency.

\section{Cite as:}

De Smet, M., Brand-Gruwel, S., Leijten, M., \& Kirschner, P. A. (2014). Electronic outlining as a writing strategy: Effects on students' writing products, mental effort and writing process. Computers \& Education, 78, 352-366.

doi:10.1016/j.compedu.2014.06.010 